\title{
PENGARUH PENDIDIKAN KESEHATAN DENGAN METODE SIMULASI PERTOLONGAN PERTAMA (LOG ROLL) PADA KORBAN DENGAN INDIKASI CEDERA TULANG BELAKANG DI PENDIDIKAN INFORMAL KECAMATAN TEMPURAN MAGELANG
}

\author{
Akhmad Rifai, Moh Ilyas \\ Poltekkes Kemenkes Surakarta Jurusan Keperawatan
}

\begin{abstract}
Background: Prevalence in Indonesian society in 2007 was 7.5\%, with several factors causing traffic and crossing sharp/ blunt objects. In 2013 there was an increase in the prevalence of trauma to $8.2 \%$, with the highest order of injuries being down $40.9 \%$, motorcycle accidents (40.6\%), trauma due to sharp / blunt objects $7.3 \%$, other land transportation 7, $1 \%$ and $2.5 \%$ fallout. To equip ordinary students in carrying out the Log roll Skills to help victims with spinal trauma need to do log roll Skills training. In this regard, researchers intend to conduct research on "The Effect of Health Education with First Aid (Log Roll) Simulation Methods on Spinal Injuries in Tempuran Informal Education in Magelang". Methods: This research is an experimental research with PreTest-Post Test Group design approach. through hypothesis testing research. The population of this research was 50 people in the cloud (Ponpes Roudlotuttulab students). Statistical test on paired groups using nonparametric Wilcoxon test. Result: Based on the Wilcoxon test results, it can be concluded that 50 respondents who log roll training can be drawn in the conclusion that the majority of students have a basic score of 0.001 which means there is a difference that takes place between before and after training. Conclusion: The suggestion put forward in this study is that education and log roll action training for lay people, especially students, continues to be held at other Islamic boarding schools to improve the skills of log roll action skills suspected in victims with spinal injuries.
\end{abstract}

Keywords: Student Ability Level, Action Log Roll

\section{PENDAHULUAN}

World Health Organization (2009)

melaporkan setiap tahun di seluruh dunia terjadi lebih dari 1, 2 juta orang meninggal di jalan raya dan sebanyak 20.-50 juta orang mengalami cedera tidak fatal. Sebagian besar (lebih dari 90\%) dari kematian tersebut terjadi di negara berpendapatan rendah dan menengah. Di negara berpendapatan rendah dan menengah, umur harapan hidup dan kualitas hidup lebih pendek dan lebih rendah dibandingkan dengan negara berpendapatan tinggi. Faktor cedera merupakan salah satu faktor yang berkontribusi terhadap beban yang diakibatkan oleh masalah kesehatan dan disabilitas (Hofman K et al., 2005).

Prevalensi cedera pada masyarakat di Indonesia pada tahun 2007 sebesar $7,5 \%$, dengan urutan penyebab cedera terbanyak adalah jatuh, kecelakaan lalu lintas (KLL) darat dan terluka benda tajam/ tumpul (Badan Penelitian dan Pengembangan Kesehatan, 2007). Pada tahun 2013 terdapat peningkatan 
prevalensi cedera menjadi $8,2 \%$, dengan urutan penyebab cedera terbanyak adalah jatuh 40,9\%, kecelakaan sepeda motor $(40,6 \%)$, cedera karena benda tajam/tumpul 7,3\%, transportasi darat lainnya $7,1 \%$ dan kejatuhan 2,5\% (Badan Penelitian dan Pengembangan Kesehatan RI, 2013).

Cedera servikal merupakan cedera tulang belakang yang paling sering menimbulkan kecacatan dan kematian, dari beberapa penelitian terdapat korelasi antara tingkat cedera servikal dengan morbiditas dan mortalitas, yaitu semakin tinggi tingkat cedera servikal semakin tinggi pula morbiditas dan mortalitasnya (Milby, 2008; Ning GZ, 2011). Cedera sumsum tulang belakang merujuk pada semua cedera di sumsum tulang belakang yang disebabkan oleh trauma benturan atau pukulan, bukan penyakit. (Taber, C. Wilbur 2009) Gejala cedera ini sangat bervariasi, tergantung pada letak sumsum tulang belakang dan akar saraf yang rusak, mulai dari nyeri, kelumpuhan, hingga inkontinensia. ( Lin VWH,2002)

$L O G$ ROLL adalah sebuah teknik yang digunakan untuk memiringkan klien yang badannya setiap saat dijaga pada posisi lurus sejajar (seperti sebuah batang kayu). Teknik ini membutuhkan 2-5 orang. Untuk klien yang mengalami cidera servikal.

Telah dilaporkan kasus cedera servikal medula spinalis yang inkomplit. Penata-laksanaan dengan stabilisasi leher, tata-laksana umum cedera leher, pemberian metilprednisolon dosis tinggi, pencegahan komplikasi, dan fisioterapi teratur. Setelah perawatan, pasien menunjukkan kemajuan yang berarti, baik fungsi motorik maupun sensorik. (Junita Maja P. S. 2013)

\section{METODE PENELITIAN}

Jenis penelitian ini adalah penelitian eksperimen. dengan deskriptif analitik dengan pendekatan crosssectional. Pengumpulan data pada penelitian ini dilakukan dengan memberikan kuesioner, sebelum pelatihan dan melakukan pelatihan cara menolong korban yang di curigai fraktur tulang belakang dan observasi setelah pelatihan yang bertujuan untuk menganalisa variabel bebas dan variabel terikat. Pelaksanaan teknik sampling dalam penelitian ini menggunakan random sampling dengan cara memilih secara acak dari 300 populasi sebesar 50 responden. Dengan menggunakan uji beda Willcoxon

\section{HASIL PENELITIAN}

Tabel 1. Distribusi Frekuensi Berdasarkan Umur

\begin{tabular}{ccc}
\hline Umur & Jumlah & $\begin{array}{c}\text { Prosentase } \\
(\boldsymbol{\%})\end{array}$ \\
\hline 15-20 Tahun & 19 & 38 \\
21-25 Tahun & 58 & 58 \\
26-30 Tahun & 2 & 4 \\
\hline Jumlah & $\mathbf{5 0}$ & $\mathbf{1 0 0 . 0}$ \\
\hline Hasil & penelitian & menunjukkan
\end{tabular}

bahwa responden dengan umur $15-20$ tahun yaitu 19 orang (38\%), umur $21-25$ tahun 58 orang $(58 \%)$ dan umur 17 ahun sebanyak 4 orang $(11,4 \%)$. Sedangkan umur 26 - 30 tahun 2 orang (4\%). Sehingga tabel di atas dapat disimpulkan bahwa mayoritas responden berumur antara $21-25$ tahun 
Tabel 2. Distribusi Frekuensi Berdasarkan Jenis Kelamin

\begin{tabular}{|c|c|c|}
\hline $\begin{array}{l}\text { Jenis } \\
\text { Kelamin }\end{array}$ & Jumlah & Prosentase $(\%)$ \\
\hline Laki - laki & 25 & 50 \\
\hline Perempuan & 25 & 50 \\
\hline Total & 30 & 100 \\
\hline
\end{tabular}

bahwa 25 responden, responden dengan jenis kelamin laki-laki adalah 25 orang (50\%) sedangkan dengan jenis kelamin peempuan adalah 25 orang (50\%), sehingga dapat disimpulkan bahwa antara reponden laki-laki dan perempuan jumlahnya sama

Tabel 3. Distribusi Frekuensi Berdasarkan Tingkat Pendidikan

\begin{tabular}{|c|c|c|}
\hline Tk Pendidikan & Jumlah & Prosentase (\%) \\
\hline SD & 5 & 10 \\
\hline SMP & 54 & 68 \\
\hline SMA & 11 & 22 \\
\hline Total & 50 & 100 \\
\hline
\end{tabular}

dengan tingkat pendidikan SD sebanyak 5 orang $(10 \%)$, SMP 34 orang $(68 \%)$, dan SMA 11 orang (22\%). Sehingga dapat disimpulkan bahwa mayoritas responden berpendidikan SMP

Tabel 4. Tingkat Kemampuan Responden sebelum dan sesudah Pelatihan log roll

\begin{tabular}{lllll}
\hline Variabel & \multicolumn{4}{c}{ Pelatihan log roll } \\
\hline & Pre & Post & \\
\hline $\mathrm{n}$ & $\%$ & $\mathrm{n}$ & $\%$ \\
\hline
\end{tabular}

\begin{tabular}{llllll}
\hline Tingkat & Kurang & 38 & 76 & 0 & 0 \\
kemampuan Log & Cukup & 12 & 24 & 19 & 38 \\
roll & Baik & 0 & 0 & 31 & 62 \\
\hline
\end{tabular}

Tabel diatas menyajikan hasil dari 50 responden, dengan tingkat kemampuan Tindakan log roll sebelum pelatihan kurang 38 responden (38\%) cukup 12 responden (24\%) dan hasil sesudah dilakukan pelatihan dengan hasil tidak ada (0\%) cukup 19 responden
(38\%) dan dengan hasil baik 31 responden $(62 \%)$.

Tabel 5. Hasil analisis uji Willcoxon tingkat kemampuan responden Sebelum dan Sesudah dilakukan pelatihan Log roll

\begin{tabular}{cccc}
\hline Variabel & $\mathrm{N}$ & Median & $\begin{array}{c}\text { Min- } \\
\text { Max }\end{array}$ \\
\hline
\end{tabular}

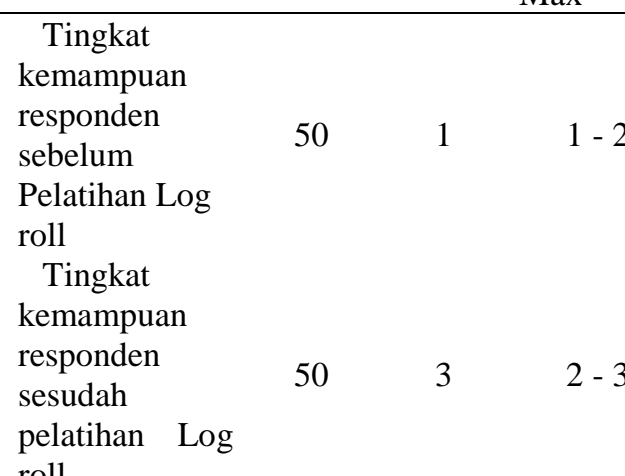

roll

Berdasarkan tabel 5 dari 50 responden, Tingkat kemampuan Log roll sebelum pelatihan dengan hasil median 1 dan minimal 1 dan maksimal 2 sedangkan pada Tingkat kemampuan log roll sesudah pelatihan dengan hasil median 3 dan minimal 2 dan maksimal 3 . Adapun hasil dari $\mathrm{P}$ value 0,001 yang artinya ada perbedaan yang signifikan antara sebelum dan sesudah dilakukan pelatihan log roll

\section{PEMBAHASAN}

Menurut Ahmad Tafsir, "Istilah Pesantren adalah lembaga Pendidikan Islam tertua di Indonesia yang telah berfungsi sebagai salah satu pusat dakwah dan pusat pengembangan masyarakat muslim Indonesia" (2008: 120). Jadi 62 pondok pesantren sebagai tempat untuk belajar ilmu agama Islam sekaligus juga tempat tinggal para santri. Sedangkan pondok, masjid, kiai, santri, dan pengajian kitab-kitab klasik merupakan lima elemen dasar bagi pondok pesantren (Daulay: 2001) 
Tempat dan lokasi penelitian ini adalah di Ponpes pendidikan informal yaitu di Ponpes Roudlotuttulab di Wonosari, Prajegsari kecamatan Tempuran kabupaten Magelang. Sebelum pemberian materi pelatihan tindakan log roll pada responden, terlebih dahulu dilakukan pre test untuk mengukur tingkat kemampuan responden. Pelaksanaan pelatihan responden di bagi menjadi 2 kelas, setiap kelas terdiri dari 25 responden. Yaitu laki-laki 25 orang dan perempuan 25 orang. Hasil dari penelitian ini didapakan bahwa jumlah responden sebanyak 50 responden yang terdiri lakilaki $50 \%$ dan $50 \%$ permpuan, jadi jumlahnya antara laki-laki dan perempuan. umur rata-rata diantara 21 sampai dengan 25 tahun atau rata-rata $58 \%$, sedangkan pendidikan rata-rata SMP sebear $68 \%$.

Hasil penelitian menunjukkan bahwa dari 50 responden, sebelum dilakukan pelatihan $\log$ roll terdapat 38 orang $(76 \%)$ dengan tingkat kemampuan kurang, tingkat kemampuan cukup ada 12 orang (24\%) dan tingkat kemampuan baik tidak ada. Hasil uji hipotesis menggunakan uji non parametric Wilcoxon , Tingkat kemampuan melakukan log roll dengan nilai $\mathrm{p}$ value $=0,001$ yang berarti bahwa setelah dilakukan pelatihan tindakan log roll ada perbedaan yang bermakna terhadap Tingkat kemampuan melakukan log roll pada Siswa atau santri pada penddikan informal. Ketepatan tindakan log roll pada pasien atau korban dengan cedera tulang belakang akan mengurangi resiko cedera tulang belakang yang berkelanjutan. Hal ini juga didukung oleh Dampak cedera yaitu lama rawat inap akibat cedera tidak berbeda berdasarkan jenis pekerjaan. aktor yang berperan terhadap lama rawat inap adalah jenis, penyebab, dan tempat kejadian cedera. Lama rawat inap 7 hari ke atas berperluang berisiko 21 kali pada jenis cedera gegar otak, 6,3 kali pada cedera patah tulang, 3 kali pada cedera mata, 2,1 kali pada cedera KLL, dan 1,7 kali pada cedera yang terjadi di bisnis/industri/ konstruksi/pertanian ( Tana. L 2016). Telah dilaporkan kasus cedera servikal medula spinalis yang inkomplit. Penatalaksanaan dengan stabilisasi leher, tata-laksana umum cedera leher, pemberian metil prednisolon dosis tinggi, pencegahan komplikasi, dan fisioterapi teratur. Setelah perawatan, pasien menunjukkan kemajuan yang berarti, baik fungsi motorik maupun sensorik (Junita Maja P. S. 2013)

Tulang belakang dan kepala merupakan bagian yang harus dianggap satu kesatuan jika berhubungan dengan trauma. Semua segmen tulang belakang sangat rentan terhadap trauma. Trauma tulang belakang bagian servikal merupakan bagian yang menjadi perhatian khusus ahli patologi forensik karena berhubungan dengan cedera kepala. Kekerasan pada kepala cendrung merusak bagian leher. Kerusakan tulang belakang dapat disebabkan oleh kompresi, tekanan hiperfleksi dan hiperekstensi. Pada laporan kasus ini dibahas tentang multiple trauma pada korban yang sudah membusuk dengan fokus ke cedera tulang belakang dan medulla spinalis sebagai penyebab utama kematian korban. (Susanti R dan Hidayat.T 2017)

Masyarakat Indonesia sudah banyak yang mengetahui pentingnya pertolongan pertama namun tidak sampai pada tahap mempelajari. Selain itu masyarakat beranggapan bahwa pertolongan pertama berguna ketika situasi gawat darurat yang mungkin tidak 
akan mereka alami. Masyarakat perlu ditingkatkan kesadarannya dan diberi sebuah fasilitas yang mudah dijangkau untuk mempelajari pertolongan pertama (Fadhillah, 2013). Perlu diingat bahwa pertolongan pertama yang diberikan ketika kecelakaan merupakan bantuan yang sangat mendesak dan sangat dibutuhkan. Mendesak karena pada saat itu paramedis tidak langsung mendatangi korban 87 (Cho, 2015). Meskipun demikian, tanpa didasari dengan pengetahuan yang benar tentang pertolongan pertama, masyarakat seringkali menjadi panik dan tidak tahu harus berbuat apa ketika menghadapi kondisi darurat tersebut. Sehingga, karena salah penanganan dari awal itulah justru memperparah situasi serta kondisi korban (Kumoratih, 2010)

Selama pelaksanaan penelitian ini terdapat beberapa kendala, diantaranya adalah pada saat pre test dan post test, responden tetap duduk berdampingan ecara lesehan dan membaur sehingga memungkinkan responden melakukan diskusi tentang jawaban pertanyaan dari kuesioner tersebut. Seharusnya pada saat test berlangsung tempat duduk responden diberi jarak selayaknya pada saat pelaksanaan ujian. Sehingga dengan adanya kendala tersebut, perlu dilakukannya penelitian selanjutnya dengan waktu yang lebih lama, dan khusus hanya untuk pemberian materi BHD serta pengaturan ruang yang memadai sehingga memaksimalkan hasil penelitian.

\section{KESIMPULAN DAN SARAN}

Hasil penelitian terhadap 50 responden tentang pelatihan tindakan $\log$ roll pada korban yang di curigai dengan cedera tulang belakang dapat disimpulkan sebagai berikut :

1. Para siswa dengan pendidik informal sebelum di lakukan pelatihan tindakan log roll tinkat kemampuannya kurang

2. Sesudah diberikan pelatiahn tentang tindakan log roll 19 orang (38\%) dengan tingkat kemampuan cukup dan tingkat kemampuan baik ada 31 orang $(62 \%)$

3. Ada pengaruh yang signifikan antara sebelum dan sesudah dilakukan pelatihan tindakan log roll di Pon pes roudlotuttulab Wonosari Prajegsari Tempuran Magelang

Penanganan Cedera tulang belakang harus di miliki oleh setiap orang baik orang awam,awam khusus terlebih tenaga kesehatan sehingga jika sesorang menemukan penyitas yang mengalami atau yang dicurigai cedera tulang belakang dapat melakukan tindakan log roll dengan benar

\section{DAFTAR RUJUKAN}

Berman, A. et al. 2009. Buku Ajar Praktik Keperawatan Klinis Koizer \& Erb, Edisi 5. Jakarta: EGC.

Hidayat, Aziz. (2008). Metode Penelitian Keperawatan dan teknik analisis data. Jakarta. Salemba medika.

Hofman K, Primack A, Keusch, G, Hrynkow S. 2005. Addressing the growing burden of trauma and injury in low-and middle-income countries. American Journal of Public Health, Vol. 95, No. 1, pp. 13-17.

Junita Maja P. S.(2013) Diagnosis Dan Penatalaksanaan Cedera Servikal Medula Spinalis Jurnal Biomedik (JBM), Volume 5, Nomor 3, November 2013, hlm. 181-189 
Krisanty P., dkk. (2016). Asuhan Keperawtan Gawat Darurat. Jakarta: TIM

Lin VWH; Cardenas DD; Cutter N.C.; Frost F.S.; Hammond M.C. (2002). Spinal Cord Medicine: Principles and Practice. Demos Medical Publishing

Milby, A.H., Halpern, C.H., Guo, W., Stein, S.C. 2008. Prevalence of cervical spinal injury in trauma. Neurosurg Focus, 25(5): E1-10.

Narayan RK, Wilberger JE, Povlishock JT. (1996) Spinal cord injury. In: Narayan RK, editor. Neurotrauma Vol II. Mc-Graw-Hill. New York. 1996; II;1041-112.

Nursalam. (2008). Konsep dan Penerapan Metodologi Penelitian Ilmu Keperawatan. Edisi 2. Jakarta : Salemba Medika.

Taber, C. Wilbur; Venes, Donald (2009). Taber's Cyclopedic Medical Dictionary. F.A. Davis. hlmn. 2173-4. ISBN 0-8036-1559$\underline{0}$.

Tani, L (2016) Faktor yang berperan pada lama rawat inap akibat cedera pada kelompok pekerja usia produktif di Indonesia. Buletin peelitian sistem kesehatan- Vol.19. No.1 Januari $2016: 75-82$

World Health Organization. (200. Global status report on road safety: time for action. Geneva. Available at: www.who.int/violence injury_pre vention/road_safety_status/2009. [Accessed 5 Februari 2015].

Junita Maja P. S. ( 2016) Diagnosis dan penatalaksanaan cedera servikal modula spinalis. Jurnal Biomedik (JBM), Volume 5, Nomor 3, November 2013, hlm. 181-189
Susanti R dan Hidayat.T (2017) Kematian pada kasus cedera tulang belakang bagian servikal akibat kekerasan. Prosiding Pertemuan Ilmiah Tahunan Perhimpunan Dokter Forensik Indonesia

Tarwoto dan Wartonah. (2015). Kebutuhan Dasar Manusia dan Proses Keperawatan. Jakarta : Salemba Medika

Triyanta. (2011). Jurnal Hubungan antara Kualitas Tidur dengan Denyut Jantung Dilihat dari Gambaran EKG pada Pasien Infark Miokard di Ruang ICVCU RSUD Dr. Moewardi Surakarta Tahun 2011 